\title{
Ecological comparative assessment of selected materials used for the construction of spark ignition engines
}

\begin{abstract}
The aim of the article is to present the environmental effects of changes in material composition in selected internal combustion engines used in passenger cars using LCA analysis. The levels of energy consumption and emissions of pollutants related to material inputs occurring at the stage of engine production have been determined. The simplified LCA model presented in the paper shows the energy consumption and total $\mathrm{CO}_{2}$ and $\mathrm{SO}_{2}$ emissions on the basis of the mass of materials from which the engine is made. The research results presented in the paper give a picture of a modern passenger car engine on the basis of wear and the degree of recovery of materials used for its construction.
\end{abstract}

Key words: engine, passenger car, life cycle analysis, eco-design, environmental protection

\section{Introduction}

Along with the civilization development of the world, the awareness of the current environmental threats and the great need to counteract them increases. This is especially evident in the automotive field, where the environmental protection issues have recently become more and more focused. Currently, the ecological properties of vehicles, apart from the safety systems used, are very often considered to be determinants of technological progress in the automotive industry. Concerns about the negative impact of road transport on the environment are potentiated by the constantly growing number of cars in the world. Limiting the degradation of the environment by road transport is done by legal regulations, which are to contribute to the elimination of technologies harmful to the environment. Stricter environmental standards put the automotive industry under increasing pressure to reduce fuel consumption and exhaust emissions over the lifetime of a car. Hence, most of the research described in the world literature focuses on reducing energy consumption and emissions of toxic compounds and $\mathrm{CO}_{2}$ directly related to the operation of the vehicle. Most often they relate to the environmental impact assessment of unconventional drives and alternative fuels. Nevertheless, the largest number of vehicles traveling on the road are still cars with classic spark-ignition combustion engines.

The main component of any vehicle is a car engine. Drives used in passenger vehicles are subject to diversification with the progress of civilization. Spark ignition (SI) engines are widely used in motor vehicles due to their many advantages. These include mainly: high reliability, durability, reduction of fuel consumption and minimization of their harmful impact on the natural environment. Obtaining the best performance indicators of an internal combustion engine has attracted the attention of designers and researchers from the first years of their creation. In the past, they were designed precisely for high performance. Currently, the most important stimulus for their development is low environmental impact. The aim is to minimize the emission of toxic substances and noise as well as low fuel consumption. Requirements for the ecological properties of engines are put forward both by the environmental protection authorities and by the users themselves, which proves a significant increase in the environmental awareness of the present society.

The modern power supply systems for SI engines differ significantly from the power systems from the end of the $20^{\text {th }}$ century. Until the $1990 \mathrm{~s}$, the most widely used system was the carburetor. However, the introduction of Euro standards in Europe and the increase in fuel prices forced manufacturers to develop a modern petrol injection system. These systems allowed to reduce fuel consumption and emission of harmful exhaust components to the atmosphere. At the turn of the 70's and 80's, injection power and threeway exhaust gas catalysts were introduced in spark ignition engines. This caused a certain stagnation in their development, which lasted until the mid-90s. Contamination of the natural environment caused by the exploitation of means of transport is part of the global ecological problem and is the subject of many activities of governmental and non-governmental organizations, especially in the legislative sphere. This obviously forces manufacturers of SI engines to create new generations of vehicles in terms of design, technology and functionality. Therefore, the development of environmental protection requirements has become the main factor stimulating the development of modern designs of engines used in passenger vehicles $[1,2]$.

The traditional approach to the environmental assessment of a car consists mainly in determining the emissions of pollutants and $\mathrm{CO}_{2}$ depending on the amount of fuel used by the vehicle. Existing emission standards are the result of this approach. The life cycle methodology (LCA) used in the work, described in ISO 14040 [3] and 14044 [4], expresses a contemporary approach to the problem of the impact of a car and its components on the environment. These standards define the method of comprehensive, quantitative determination of the environmental load, based on the inventory of environmental factors related to a facility, process or other activity over the entire cycle from the extraction of raw materials to their final management [5-7]. The LCA method, introduced since the 1970s [9, 10], is one of the most effective and reliable eco-balance tools that allow to assess the amount of energy consumption and the amount of emissions of hazardous substances and materials in all phases of the product's existence - starting from obtaining raw materials, and ending with the disposal of used 
up products. This forms the basis for estimating the options available to reduce these loads introduced into the environment.

The aim of the article is to present the environmental effects of changes in material composition in selected internal combustion engines used in passenger cars using the LCA method.

\section{Modeling the life cycle of SI engine}

\subsection{Research objects}

The subjects of the research were SI engines, which currently selected Hyundai and Ford vehicles are equipped with. These are petrol engines with similar operational characteristics, manufactured since 2005. Table 1 presents the basic technical data.

Table 1. Basic technical parameters of internal combustion engines tested

\begin{tabular}{|l|c|c|c|c|}
\hline $\begin{array}{l}\text { Engine } \\
\text { specifications }\end{array}$ & $\begin{array}{c}\text { Hyundai I30 } \\
1.4\end{array}$ & $\begin{array}{c}\text { Focus III } \\
1.6 \text { Eco- } \\
\text { boost }\end{array}$ & Focus I 1.8 & Fiesta 1.4 \\
\hline $\begin{array}{l}\text { Year of } \\
\text { construction }\end{array}$ & 2016 & 2014 & 2005 & 2013 \\
\hline $\begin{array}{l}\text { Cubic } \\
\text { capacity }\end{array}$ & $1396 \mathrm{~cm}^{3}$ & $1596 \mathrm{~cm}^{3}$ & $1796 \mathrm{~cm}^{3}$ & $1388 \mathrm{~cm}^{3}$ \\
\hline Engine type & petrol & petrol & petrol & petrol \\
\hline $\begin{array}{l}\text { Engine } \\
\text { power }\end{array}$ & $\begin{array}{c}100 \mathrm{KM} \\
(74 \mathrm{~kW}) \text { at } \\
5500 \mathrm{rpm}\end{array}$ & $\begin{array}{c}150 \mathrm{KM} \\
(110 \mathrm{~kW}) \text { at } \\
5700 \mathrm{rpm}\end{array}$ & $\begin{array}{c}115 \mathrm{KM} \\
(85 \mathrm{~kW}) \text { at } \\
5750 \mathrm{rpm}\end{array}$ & $96 \mathrm{KM}$ \\
\hline $\begin{array}{l}\text { Maximum } \\
\text { torque }\end{array}$ & $\begin{array}{c}137 \mathrm{Nm} \text { at } \\
4200 \mathrm{rpm}\end{array}$ & $\begin{array}{c}240 \mathrm{Nm} \text { at } \\
1900-3500 \\
\text { rpm }\end{array}$ & $\begin{array}{c}158 \mathrm{Nm} \text { at } \\
3750 \mathrm{rpm}\end{array}$ & $\begin{array}{c}125 \mathrm{Nm} \text { at } \\
4200 \mathrm{rpm}\end{array}$ \\
\hline $\begin{array}{l}\text { Number of } \\
\text { cylinders }\end{array}$ & 4 & 4 & 4 & 4 \\
\hline $\begin{array}{l}\text { Arrangement } \\
\text { of cylinders }\end{array}$ & in-line & in-line & in-line & in-line \\
\hline $\begin{array}{l}\text { Number of } \\
\text { valves }\end{array}$ & 16 & multi-point \\
\hline (MPI) & direct & $\begin{array}{c}\text { multi-point } \\
\text { (MPI) }\end{array}$ & $\begin{array}{c}\text { multi-point } \\
\text { (MPI) }\end{array}$ \\
\hline Injection type & $\begin{array}{c}16 \\
16\end{array}$ & & \\
\hline
\end{tabular}

\subsection{LCA}

The environmental safety of a car is currently one of the most important indicators determining the quality and competitiveness of a car on global markets. One of the priorities in the design of all technical facilities is currently to reduce their impact on the natural environment. This also applies to internal combustion engines. They are commonly seen as one of the sources of significant changes in the environment. Efforts undertaken so far to improve the environmental image of internal combustion engines were usually aimed at reducing the amount of exhaust fumes. However, the causes of environmental degradation related to internal combustion engines are much more complex. They are not limited to the consequences of the combustion process, but also result from the use of natural resources for the production of engines and from production processes, which are always accompanied by environmental impact. During the operation of internal combustion engines, noise is emitted and repairs are made, and after the end of the engine life it becomes important whether its parts can be recycled. These aspects should be taken into account by designers who comprehensively care about the environmental image of engines. Only then will their activities aimed at limiting the environmental impacts generated in the entire life cycle of internal combustion engines be consistent with contemporary trends in their design [8].

One of the most effective methods for the effective assessment of a product's environmental impact is the Life Cycle Assessment LCA. It is defined as a method of quantifying the environmental load, based on an inventory of environmental factors related to a facility, process or other activity in the cycle from the extraction of raw materials to their final use [9]. It is primarily used to determine the environmental impacts of the processes related to the entire contractual lifetime of the product, starting from the manufacturing of materials, through production, its use until its withdrawal from use. This approach is needed especially for passenger cars, and thus internal combustion engines, where special attention should be paid to the materials needed for their production. These mainly include metals, plastics, glass, rubber and ceramics, as well as fabrics and others. The production of these materials and then the components needed for the mass production of vehicles on an unprecedented scale requires the use of limited natural resources and energy in production processes, which is always accompanied by a negative impact on the environment [8].

The result of using the LCA method to analyze the environmental impacts of a facility is the eco-indicator in the form of a single number or an environmental profile, which is a characteristic indicating the size of the generated environmental loads within individual impact categories. Due to the simple and legible way of presenting the results, LCA is a method particularly appreciated by engineers dealing with the issues of environmental optimization of mechanical structures $[9,10]$.

\subsection{Data sources}

Life Cycle Inventory (LCI) data includes product data and process data. Product data is characterized by the tested car engines. According to the scope of the assessment, this is information about the parts and materials from which they were made. The data also includes information on fuel consumption and pollutant emissions during use, as well as information on the rates of material recovery and reuse in accordance with the applicable policy rules that regulate these issues $[11,12]$. Process data, on the other hand, includes information on processing the processes in the production of materials and parts used to build internal combustion engines.

Material data on the tested engines of Ford and Hyundai vehicles was obtained during inventory studies carried out at a certified vehicle dismantling station in Szczecin, Poland and at an authorized Ford service center in Szczecin. As part of the tests at the dismantling station, the tested engines were disassembled into assemblies and individual parts. During the tests carried out at an authorized service point, the engines disassembled from the repaired cars and kept in stock were used. In order to prepare a list of materials used in cars, these materials were identified, weighed and their type was determined. Many small parts were made of one material and a similar technology. In this case, the parts list stated their total mass in kilograms. Missing material data on some components of the tested engines was obtained from the commercial IDIS database. 
The list of parts prepared in this way, together with information on the weight of materials, was used to build the LCA model of the car engine. As the obtained parts are made of different components, in order to simplify the model and facilitate the presentation of the life cycle assessment results, the materials have been assigned to three groups:

- steel,

- aluminum,

- other materials.

Inputs include streams of the materials used in the engine, which come from the environment (primary production), and recycling (secondary production). The system outputs include pollutant emissions and the energy consumption associated with their generation.

For each material stream, the emission levels of substances were determined, such as $\mathrm{CO}, \mathrm{CO}_{2}, \mathrm{CH}_{4}, \mathrm{~N}_{2} \mathrm{O}$, $\mathrm{NO}_{\mathrm{x}}$, NMVOC which accompany primary and secondary production of materials. Data on the size of these emissions were obtained from the Ecoinvent 2.1 database, which is commonly used in life cycle tests [12]. The environmental impact of these variables was converted into emissions of carbon dioxide $\mathrm{CO}_{2} \mathrm{eq}$ and sulfur dioxide $\mathrm{SO}_{2}$. The EcoIndicator EI99 E/A Europe method was used for the conversion. In the LCA studies, the total emission of $\mathrm{CO}_{2 \text { eq }}$ and $\mathrm{SO}_{2}$ was treated as an environmental impact category. On the other hand, energy consumption in material production processes was determined on the basis of the SimaPro and Greet databases.

\section{The results of the comparative assessment}

In order to perform a quantitative ecological comparative assessment of materials used in the construction of a car engine, an identification of the engine construction phase model was carried out on the basis of the collected research material covering 4 selected vehicles from two manufacturers belonging to segment $\mathrm{B}$, which were produced in 2005-2016. This required determining the mass of the materials that make up each engine. The obtained material data reflects changes in the design of selected combustion engines of passenger cars. Table 2 presents the masses of materials from which the tested internal combustion engines are made. It was assumed that the level of energy consumption and emissivity in the construction phase of selected engines can be determined based on changes in the material structure.

Table 2. Material mass in $\mathrm{kg}$

\begin{tabular}{|l|c|c|c|}
\hline \multicolumn{1}{|c|}{ Engine } & aluminum & steel, cast iron & other \\
\hline $\begin{array}{l}\text { Hyundai I30 1,4 } \\
\text { petrol 80 kW }\end{array}$ & 43.48 & 15.57 & 3.22 \\
\hline $\begin{array}{l}\text { Focus III 1,6 } \\
\text { ecoboost 110 kW }\end{array}$ & 44.75 & 21.21 & 2.15 \\
\hline $\begin{array}{l}\text { Focus I 1,8 } \\
\text { petrol 85 kW }\end{array}$ & 15.8 & 71.51 & 2.94 \\
\hline $\begin{array}{l}\text { Fiesta 1,4 } \\
\text { petrol 60 kW }\end{array}$ & 13.9 & 76.33 & 2.9 \\
\hline
\end{tabular}

The percentages of basic materials in the Hyundai I30 1.4 petrol $80 \mathrm{~kW}$ and Focus III 1.6 Ecoboost $110 \mathrm{~kW}$ engines are similar. They are characterized by a high (over $65 \%$ ) share of aluminum. In turn, the Focus I 1.8 petrol
$85 \mathrm{~kW}$ and Fiesta 1.4 petrol $60 \mathrm{~kW}$ engines are characterized by a very high (approx. 80\%) share of steel and cast iron. This relationship is shown in Fig. 1.

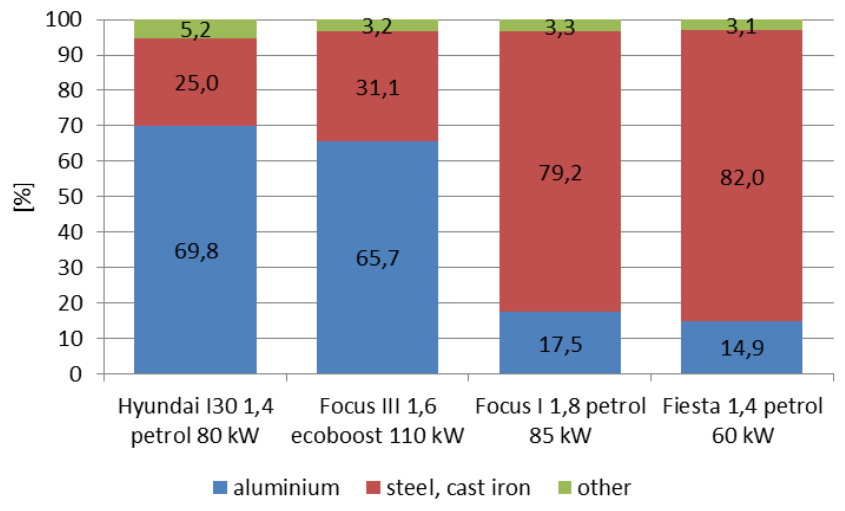

Fig. 1. Percentage of materials

Such distribution of materials in the presented engines results in a different percentage of energy expenditures and $\mathrm{CO}_{2}$ and $\mathrm{SO}_{2}$ emissions.

For energy expenditures (Fig. 2) in the Hyundai I30 1.4 petrol $80 \mathrm{~kW}$ and Focus III 1.6 Ecoboost $110 \mathrm{~kW}$ engines, aluminum had the greatest impact. Its share in energy expenditures was at the level of approx. 90\%. In the Focus I 1.8 petrol $85 \mathrm{~kW}$ and Fiesta 1.4 petrol $60 \mathrm{~kW}$ engines, steel and cast iron accounted for slightly more than half of the share of energy expenditures (52.7-57.5\%).

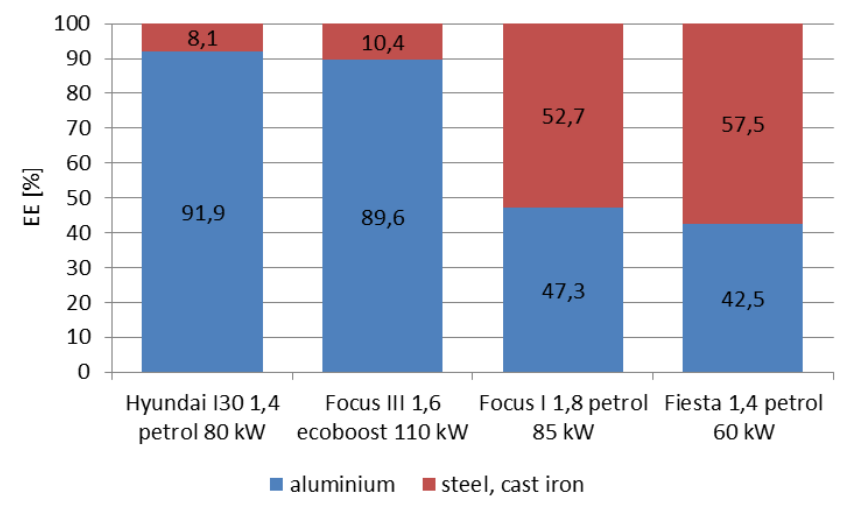

Fig. 2. Percentage of energy expenditure

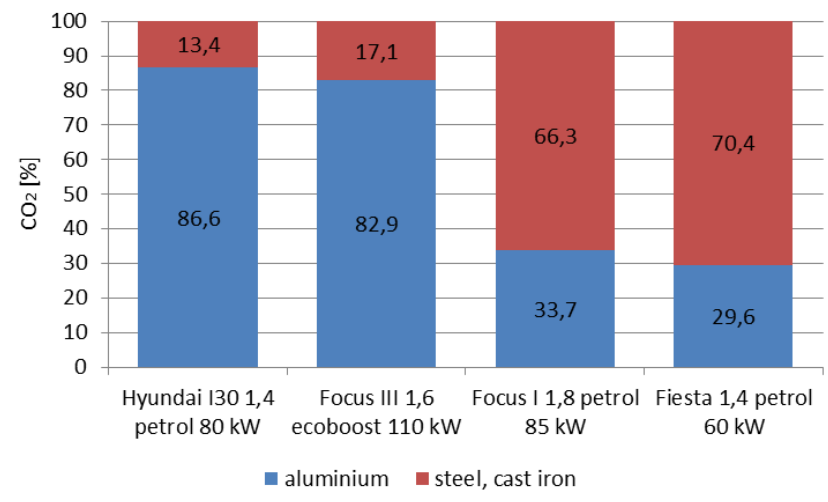

Fig. 3. Percentages of $\mathrm{CO}_{2}$ emissions 


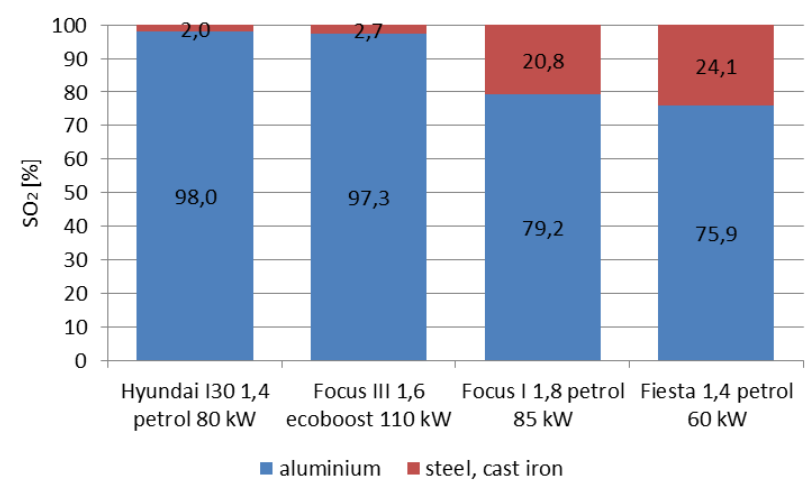

Fig. 4. Percentages of $\mathrm{SO}_{2}$ emissions

For $\mathrm{CO}_{2}$ and $\mathrm{SO}_{2}$ emissions (Fig. 3 and Fig. 4) in the Hyundai I30 1.4 petrol $80 \mathrm{~kW}$ and Focus III 1.6 Ecoboost $110 \mathrm{~kW}$ engines, as well as for energy expenditures, aluminium had the greatest impact. Its share in $\mathrm{CO}_{2}$ emissions was at the level of $82.9-86.6 \%$, and in $\mathrm{SO}_{2}$ emissions - at the level of $97.3-98.0 \%$. In the Focus I 1.8 petrol $85 \mathrm{~kW}$ and Fiesta 1.4 petrol $60 \mathrm{~kW}$ engines, steel and cast iron accounted for most of the $\mathrm{CO}_{2}$ emissions (66.3-70.4\%), and aluminum for $\mathrm{SO}_{2}(79.2-75.9 \%)$.

\section{Conclusion}

The results presented in the paper present the environmental effects of changes in the material composition in Ford and Hyundai passenger car engines. The simplified LCA model of the engine presented in the paper shows the energy consumption and total $\mathrm{CO}_{2}$ and $\mathrm{SO}_{2}$ emissions on the basis of the obtained mass of materials. The changes in the use of materials are a signal of the technological progress that has taken place in the design of cars in recent times.

The selection of construction materials used in the construction of the tested internal combustion engines has a significant impact on the level of their environmental impact. There is a visible tendency to decrease the share of steel, cast steel and cast iron with a simultaneous increase in the share of other materials. This can be observed by systematically increasing the environmental loads associated with the use of other materials.

The percentages of basic materials in the tested engines are similar. The dominant material here is aluminum. In turn, the engines of the Focus I 1.8 petrol $85 \mathrm{~kW}$ and Fiesta 1.4 petrol $60 \mathrm{~kW}$ vehicles are characterized by a very high share of steel and cast iron.

\section{Nomenclature}

LCA Life Cycle Assessment

LCI Life Cycle Inventory

$\mathrm{CO}_{2}$ carbon dioxide

$\mathrm{SO}_{2}$ sulphur dioxide
SI spark ignition engine

NE energy expenditures

NM materials

\section{Bibliography}

[1] MERKISZ, J. Ekologiczne problemy silników spalinowych. Wydawnictwo Politechniki Poznańskiej. Poznań 1998.

[2] MERKISZ, J. Ekologiczne aspekty stosowania silników spalinowych. Wydawnictwo Politechniki Poznańskiej. Poznań 1995.

[3] International Organization for Standardization (ISO), 2006. 14040 - Environmental Management. Life Cycle Assessment. Principles and Framework.

[4] International Organization for Standardization (ISO), 2006. 14040 - Environmental Management. Life Cycle Assessment. Requirements and Guidelines.

[5] PN-EN ISO 14040. Zarządzanie środowiskowe - Ocena cyklu życia - Zasady i struktura. Polski Komitet Normalizacyjny, czerwiec 2006.

[6] PN-EN ISO 14040. Zarządzanie środowiskowe - Ocena cyklu życia - Wymagania i wytyczne. Polski Komitet Normalizacyjny, lipiec 2006.

[7] KULCZYCKA, J. Ekologiczna ocena cyklu życia (LCA) nową techniką zarządzania środowiskowego. IGSMiE, Kraków 2001.

\footnotetext{
Małgorzata Mrozik, DSc., DEng. - Faculty of Mechanical Engineering and Mechatronics, West Pomeranian University of Technology in Szczecin. e-mail:mmrozik@zut.edu.pl
}

[8] MERKISZ, J., KURCZEWSKI, P., LEWICKI, R. Wybrane aspekty prośrodowiskowego projektowania silników spalinowych. Wydawnictwo Politechniki Poznańskiej. Poznań 2007.

[9] Environmental Life Cycle Assessment of products, Part 1 Guide, Part 2 - Backgrounds, NOH 1992.

[10] KOWALSKI, Z., KĘDZIERSKA, D., NOWAK, A.K. et al. LCA analysis of processing of the zinc and lead ores in Trzebionka Mining Works. 10th Conference on Environment and Mineral Processing, VŠB-TU Ostrava. Proceedings Part II, 22-24.06.2006, 105-115.

[11] Dyrektywa 2000/64/EC of the European Parliament and of the Council, On the type-approval of motor vehicles with regard to their re-usability, recyclability and recoverability and amending Council Directive 70/156/EEC, 26 November 2005, Official Journal L 310.

[12] BIRAT, J., GUERIN, V., ROCCHIA, L. et al. 2004. Ecodesign of automobiles based on the environmental properties of body materials. SAE Technical Paper. 2004-010250 . 